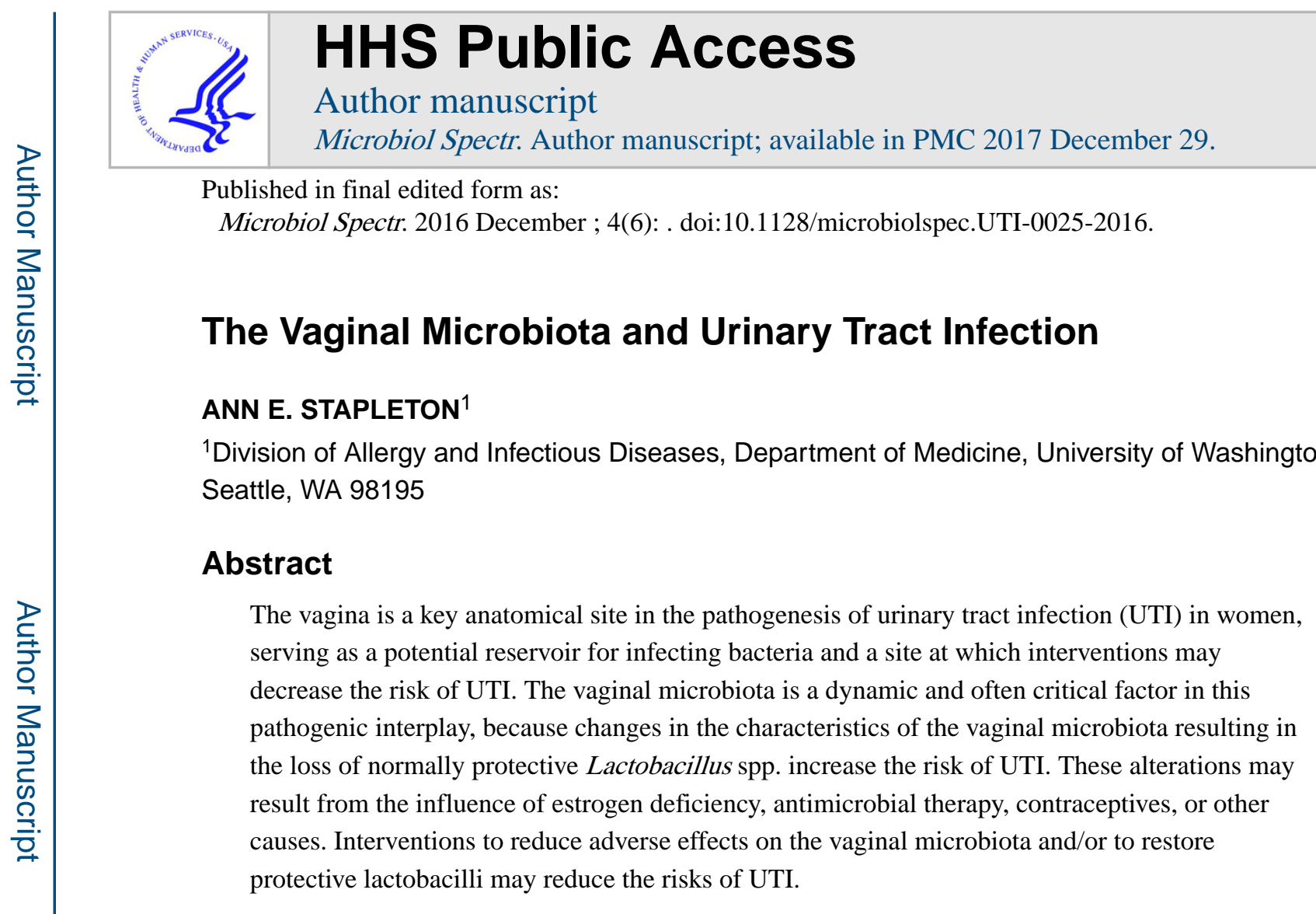

\title{
INTRODUCTION
}

Urinary tract infections (UTIs) are a common clinical problem across the lifespan of women. Although UTIs are not systematically tracked, making estimates of U.S. incidence somewhat challenging, the most recent combined National Hospital Ambulatory Medical Care Survey and National Ambulatory Medical Care Survey data from 2009-2010 suggest that approximately 10 million outpatient visits for a diagnosis of UTI occur annually in the United States among both women and men (1). Women are disproportionately affected, with an estimated lifetime risk of UTI of $60 \%$ (2). In otherwise healthy, sexually active premenopausal women, these infections occur approximately every other year (3). As women age, UTIs become more common (2). A population-based study of community-onset UTI among nearly 31,000 residents of Calgary showed that the incidence of UTI among women demonstrates an initial peak in the twenties (30 per 1,000), decreases slightly during the later reproductive years, then steadily increases with every decade of life starting in late middle age, reaching a maximum of 125/1,000 at and above age 80 (4). Although the cost of treating UTI has not been recently estimated, the last published estimate in 2010 indicated that the annual U.S. domestic cost exceeded two billion dollars (5-7).

Despite decades of studies defining the epidemiology, risk factors, and pathogenic mechanisms in UTIs, current evidence-based prevention strategies still rely upon the use of low-dose prophylactic antimicrobials as the cornerstone of prevention of recurrent UTIs in women of any age (8). For postmenopausal women, vaginal estrogen therapy may be considered, but this is often as an adjunctive to antimicrobial-based prophylaxis (8). Given

Correspondence: Ann E. Stapleton, stapl@uw.edu. 
the inexorable increase in antimicrobial resistance documented worldwide for the past few decades, antimicrobial-based preventive strategies have become less attractive and potentially contributory to worsening resistance rates (9). As discussed in detail below, the vaginal microbiota (VMB) plays a key role in the pathogenesis of UTI: alterations in the VMB are associated with risks for UTI, and effects on the VMB associated with treatment of UTIs can affect the success of this therapy. Thus, a better understanding of the role of the VMB in UTI may lead to improved interventions to prevent and treat these infections.

\section{THE ROLE OF THE VAGINA IN THE PATHOGENESIS OF UTI}

In women, the vagina plays a key role in the pathogenesis of UTIs. The intestinal microbiota is the ultimate source of bacterial strains causing cystitis and pyelonephritis in the majority of cases (10). The initial step in the pathogenesis of UTI is colonization of the vaginal introitus and periurethra with the infecting uropathogens, followed by ascension of uropathogens via the urethra to the bladder and sometimes the kidneys to cause infection (10-12). Thus, understanding factors that affect the microbiota of the vagina is key to understanding the pathogenesis of UTI and to designing interventions to prevent UTIs.

\section{PROTECTIVE ROLE OF LACTOBACILLI IN THE VAGINA}

Studies of the VMB have long indicated that certain bacterial species and/or microbial characteristics are associated with disease-free conditions, or "health," of the genitourinary tract (13). Studies specifically related to the pathogenesis of UTI largely date from decades preceding the availability of culture-independent methodologies for characterizing microbial communities, larger-scale microbial sequencing methods, and wide-spread interest in the microbiome. In culture-based studies of vaginal samples from women without urogenital disease conditions, Lactobacillus species comprise $90 \%$ of the organisms present $(14,15)$, and 80 to $90 \%$ of these lactobacilli produced $\mathrm{H}_{2} \mathrm{O}_{2}$, mostly attributable to Lactobacillus crispatus and Lactobacillus jensenii $(14,15)$. Beginning with early studies utilizing DNA hybridization and quantitative real-time PCR (RT-PCR) of lactobacilli cultured from vaginal samples, numerous studies have identified L. crispatus as the predominant species present in healthy premenopausal women (14). Many experts view the presence of L. crispatus as an overall marker of a healthy VMB (16).

Several subsequent studies have characterized the VMB in states of health and disease using culture-independent methods, largely based on 16S ribosomal RNA bacterial gene sequencing $(13,17)$. One of the first large-scale, non-culture-dependent studies of vaginal microbial communities assessed approximately 400 asymptomatic North American women, using pyrosequencing of bar-coded $16 \mathrm{~S}$ rRNA genes (18). This study confirmed that most vaginal microbial communities (73\%) were dominated by one or more species of Lactobacillus and that this genus constituted over half of all sequences obtained (18). As of 2014, a systematic review of VMB studies performed using molecular characterization methodology identified 63 studies meeting criteria for inclusion and noted that these studies have definitively demonstrated that a Lactobacillus-dominated VMB is correlated with what was termed a "healthy vaginal micro-environment" (17). 
Conversely, the absence of vaginal lactobacilli has been associated with several disease states. In earlier clinical studies, vaginal samples collected from women with and without various urogenital disease conditions were cultured using standard microbiological methods for isolating lactobacilli and were compared for characteristics such as the presence or absence of Lactobacillus spp., especially $\mathrm{H}_{2} \mathrm{O}_{2}$-producing lactobacilli. Women lacking vaginal lactobacilli per vaginal cultures, particularly those with vaginal samples with decreased relative amounts of or total absence of peroxide-producing lactobacilli, were found to be at increased risk for a variety of urogenital disease conditions, including bacterial vaginosis, HIV infection, and Neisseria gonorrhoeae, as well as vaginal colonization with Escherichia coli, the most common cause of UTI in women (19-24).

Proposed mechanisms through which lactobacilli may prevent vaginal colonization by uropathogens include competitive exclusion of uropathogens by adherence of Lactobacillus species to uroepithelial cells; lowering of vaginal $\mathrm{pH}$ by production of lactic acid; production of bacteriocins, surfactants, and other antimicrobial products; and finally, production of $\mathrm{H}_{2} \mathrm{O}_{2}$ (25-32). L. crispatus is highly adherent to vaginal epithelial cells and produces high quantities of $\mathrm{H}_{2} \mathrm{O}_{2}(29,33,34)$. Lactic acid concentrations are high in a lactobacillusdominated $\mathrm{VMB}$, and these conditions produce a potently antimicrobial environment in vitro (35). Hydrogen peroxide alone is microbicidal for many bacterial species, and this microbicidal activity is 10- to 100-fold greater when it is combined with chloride anion and myeloperoxidase, both of which are found in the vagina $(36,37)$. This vaginal antimicrobial defense system $\left(\mathrm{H}_{2} \mathrm{O}_{2}\right.$, chloride anion, and myeloperoxidase) has potent in vitro activity against $E$. coli as well as other microorganisms (38). Lactobacilli also produce surfactants that inhibit growth of E. coli and other uropathogens $(27,28)$.

\section{ALTERATIONS IN MICROBIOTA ASSOCIATED WITH UTI}

The VMB has been demonstrated to be altered at the time of UTI, in women with recurrent UTI, and following treatment of the infection, even in women without a history of recurrent UTI. As noted above, the critical event preceding UTI is colonization of the vaginal introitus with intestinal microbiota, most commonly E. coli $(36,39,40)$. Multiple culture-based studies showed that women with recurrent UTI often have increased rates of colonization with $E$. coli and depletion of the normally predominant $\mathrm{H}_{2} \mathrm{O}_{2}$-producing lactobacilli $(39,41-$ 43 ), suggesting that vaginal colonization with $\mathrm{H}_{2} \mathrm{O}_{2}$-producing lactobacilli may prevent $E$. coli vaginal introital colonization and UTI. In a case-control study, we found that women with recurrent UTI who lacked vaginal $\mathrm{H}_{2} \mathrm{O}_{2}$-producing lactobacilli had a 5-fold increased risk of $E$. coli vaginal colonization compared to women with $\mathrm{H}_{2} \mathrm{O}_{2}$-producing lactobacilli (41). In another study of reproductive-age women, $15 \%$ of 301 women who had vaginal colonization with $L$. crispatus or $L$. jensenii, both $\mathrm{H}_{2} \mathrm{O}_{2}$-producers, were colonized with $E$. coli, compared with $27 \%$ of womenwho did not have these lactobacilli species present $(P=$ 0.01) (14). A Canadian study showed that the VMB of women with recurrent UTI demonstrated a diminished lactobacillus morphotype composition resembling bacterial vaginosis pathophysiology (44). Finally, data from studies of premenopausal women in Seattle demonstrated that only $50 \%$ of women have $\mathrm{H}_{2} \mathrm{O}_{2}$-producing lactobacilli in the vagina at the time of presentation with recurrent UTI (45). 


\title{
ALTERATIONS OF THE VMB ASSOCIATED WITH LOSS OF ESTROGEN
}

\author{
Among the manifold effects of the loss of estrogen at the time of menopause are changes in \\ the vaginal microbiome of most women, decreasing the relative amounts of Lactobacillus \\ present (46-49). As noted above, rates of UTI begin to rise at the climacteric, and recurrent \\ UTIs are considered among the features of the genitourinary syndrome of menopause, which \\ is characterized by thinning of the vaginal epithelium, various symptoms associated with \\ vulvovaginal atrophy, and relative loss of lactobacilli in the VMB (50). In a study of 463 \\ community-dwelling postmenopausal women, colonization with $E$. coli was more frequent \\ in women without estrogen replacement and inversely associated with the presence of \\ Lactobacillus (51). Further, these alterations of the VMB were associated with having a \\ history of recurrent UTI (51).
}

Conversely, in the same study of community-dwelling postmenopausal women, retention of lactobacilli in the VMB at menopause was associated with having received systemic or topical vaginal hormone replacement therapy in the preceding year (51). Studies of treatment of menopause-associated estrogen deficiency with topical estrogen preparations such as estrogen cream or an estradiol-releasing vaginal ring (Estring) has been demonstrated to reduce the rate of recurrent UTI and restore vaginal lactobacilli in most women $(46-49,52)$. A recent study of microbial communities in postmenopausal women with atrophic vaginitis showed depletion of Lactobacillus spp. prior to therapy, with lowdose estrogen therapy increasing the relative amounts of Lactobacillus spp. and decreasing vaginal $\mathrm{pH}$ (53). As a result, topical vaginal estrogen therapy is recommended in the management of recurrent UTI in older women, in addition to low-dose antimicrobial therapy (54).

\section{ALTERATIONS OF THE VMB ASSOCIATED WITH ANTIMICROBIAL THERAPY}

Exposure to antimicrobials has been demonstrated in multiple studies to alter the VMB, such as during pregnancy $(55,56)$ or after therapy for bacterial vaginosis $(56,57)$. In one study, use of antimicrobials in the preceding weeks was associated with increased risk of UTI (58). The choice of antimicrobial for treatment of UTI may also affect the VMB. For example, beta lactam antibiotics are associated with less efficacy in eradicating vaginal colonization with E. coli, and clinically, these agents are more associated with rapid recurrence of UTI after therapy compared with other agents $(45,59)$. Of note, the Infectious Diseases Society of America considered adverse ecological effects of antimicrobials, termed collateral damage, as key factors in ranking recommended therapies for acute uncomplicated UTI (60).

\section{EFFECT OF CONTRACEPTIVE METHOD ON THE VMB AND RISK OF UTI}

Numerous studies have demonstrated that spermicidal products containing compounds such as nonoxynol-9 disrupt the VMB by depleting lactobacilli and increasing E. coli colonization and increasing the risk of UTI $(8,61-64)$. This adverse effect appears to be mediated by a direct toxic effect on vaginal Lactobacillus spp. (65). Data regarding other methods of contraception are more limited. Oral contraceptives appear to reduce the rate of 
bacterial vaginosis (66) but are neutral with respect to risk of UTI $(61,63,64)$. Data regarding the intrauterine device and effects on the VMB overall are conflicting, with no published studies considering the effect of this method on the risk of UTI at the time of this review (66).

\section{CLINICAL IMPLICATIONS}

The interactions between the VMB and the risks of UTI, treatment choices, and possible means of UTI prevention lead to several fairly evident clinical implications. First, lifestyle considerations may be discussed with patients. Though spermicidal contraceptives are less commonly used at present, these may be substituted with methods having a neutral effect on UTI, such as hormonal contraceptives (8). Patients and their providers may be counseled regarding current knowledge of adverse effects of antimicrobial agents and their effect upon risk of UTI. Postmenopausal women without contraindications to the use of topical hormone therapies may be offered such medications for primary or secondary prevention of UTI (8). In clinical practice, UTI episodes and subsequent clusters of recurrent UTI that are the hallmark of the natural history of recurrent UTI (67) may arise apparently spontaneously, for no known reason. However, given the evidence that alterations in the VMB are likely associated with these clinical events, the clinician may still attempt to identify and ameliorate known causes of VMB alterations.

Finally, the use of oral or intravaginal probiotics to attempt to restore protective vaginal lactobacilli is an attractive option that would, in theory, likely help reduce the use of antimicrobials in preventive strategies. Unfortunately, data on this approach are limited overall, and studies regarding reduction of UTI by means of oral probiotics are conflicting (8). An alternative approach of a vaginal $L$. crispatus probiotic directly administered to the vagina has shown promise in a small randomized, double-blind, placebo-controlled phase 2 study, in which receiving the lactobacillus probiotic $(n=50)$ was associated with decreased rates of recurrent UTI compared with placebo $(n=50)(68)$. Unfortunately, in a recent Cochrane review of all probiotic approaches to UTI prevention, few studies were adequate for inclusion, and the above-described study of a vaginal probiotic was the only one of its kind (69). Additional randomized, double-blind, placebo-controlled studies of adequate sample size using a carefully selected probiotic strain are needed to ascertain whether this approach is effective.

\section{SUMMARY}

The vagina is a key anatomical site in the pathogenesis of UTI, serving as a potential reservoir for infecting bacteria ascending from the intestinal source of uropathogenic bacteria. The vagina is also an important site at which interventions that positively affect the VMB can be instituted to attempt to decrease risk of UTI. The VMB is a dynamic and often critical factor in this pathogenic interplay, because changes in the characteristics of the VMB resulting in the loss of normally protective Lactobacillus spp. increase the risk of UTI. These alterations may result from estrogen deficiency, antimicrobial therapy, contraceptives, and

episodes of UTI itself. Interventions designed to maintain homeostasis of the VMB and/or to ameliorate adverse effects of exposures such as antimicrobials or menopause hold promise 
for future preventive or therapeutic options, potentially avoiding additional use of antibiotics.

\section{References}

1. CDC. NAMCS and NHAMCS Web Tables. Table 1. Annual number and percent distribution of ambulatory care visits by setting type according to diagnosis group: United States, 2009-2010. 2010. http://www.cdc.gov/nchs/ahcd/web_tables.htm

2. Foxman B. Urinary tract infection syndromes: occurrence, recurrence, bacteriology, risk factors, and disease burden. Infect Dis Clin North Am. 2014; 28:1-13. [PubMed: 24484571]

3. Hooton TM, Scholes D, Hughes JP, Winter C, Roberts PL, Stapleton AE, Stergachis A, Stamm WE. A prospective study of risk factors for symptomatic urinary tract infection in young women. N Engl J Med. 1996; 335:468-474. [PubMed: 8672152]

4. Laupland KB, Ross T, Pitout JD, Church DL, Gregson DB. Community-onset urinary tract infections: a population-based assessment. Infection. 2007; 35:150-153. [PubMed: 17565455]

5. Engel JD, Schaeffer AJ. Evaluation of and antimicrobial therapy for recurrent urinary tract infections in women. Urol Clin North Am. 1998; 25:685-701. x. [PubMed: 10026775]

6. Foxman B, Barlow R, D'Arcy H, Gillespie B, Sobel JD. Urinary tract infection: self-reported incidence and associated costs. Ann Epidemiol. 2000; 10:509-515. [PubMed: 11118930]

7. Hooton TM, Stamm WE. Diagnosis and treatment of uncomplicated urinary tract infection. Infect Dis Clin North Am. 1997; 11:551-581. [PubMed: 9378923]

8. Hooton, TM., Gupta, K. UpToDate. Waltham, MA: 2016. Recurrent urinary tract infection in women. [accessed 5 June 2016]

9. Gupta K, Bhadelia N. Management of urinary tract infections from multidrug-resistant organisms. Infect Dis Clin North Am. 2014; 28:49-59. [PubMed: 24484574]

10. Czaja CA, Stamm WE, Stapleton AE, Roberts PL, Hawn TR, Scholes D, Samadpour M, Hultgren SJ, Hooton TM. Prospective cohort study of microbial and inflammatory events immediately preceding Escherichia coli recurrent urinary tract infection in women. J Infect Dis. 2009; 200:528536. [PubMed: 19586416]

11. Russo TA, Stapleton A, Wenderoth S, Hooton TM, Stamm WE. Chromosomal restriction fragment length polymorphism analysis of Escherichia coli strains causing recurrent urinary tract infections in young women. J Infect Dis. 1995; 172:440-445. [PubMed: 7622887]

12. Beerepoot M, Geerlings S. Non-antibiotic prophylaxis for urinary tract infections. Pathogens. 2016; 5:5.

13. Ravel J, Brotman RM. Translating the vaginal microbiome: gaps and challenges. Genome Med. 2016; 8:35. [PubMed: 27036316]

14. Antonio MA, Hawes SE, Hillier SL. The identification of vaginal Lactobacillus species and the demographic and microbiologic characteristics of women colonized by these species. J Infect Dis. 1999; 180:1950-1956. [PubMed: 10558952]

15. Eschenbach DA, Davick PR, Williams BL, Klebanoff SJ, Young-Smith K, Critchlow CM, Holmes KK. Prevalence of hydrogen peroxide-producing Lactobacillus species in normal women and women with bacterial vaginosis. J Clin Microbiol. 1989; 27:251-256. [PubMed: 2915019]

16. Lepargneur JP. Lactobacillus crispatus as biomarker of the healthy vaginal tract. Ann Biol Clin (Paris). 2016; 74:421-427. [PubMed: 27492695]

17. van de Wijgert JH, Borgdorff H, Verhelst R, Crucitti T, Francis S, Verstraelen H, Jespers V. The vaginal microbiota: what have we learned after a decade of molecular characterization? PLoS One. 2014; 9:e105998.doi: 10.1371/journal.pone.0105998 [PubMed: 25148517]

18. Ravel J, Gajer P, Abdo Z, Schneider GM, Koenig SS, McCulle SL, Karlebach S, Gorle R, Russell J, Tacket CO, Brotman RM, Davis CC, Ault K, Peralta L, Forney LJ. Vaginal microbiome of reproductive-age women. Proc Natl Acad Sci USA. 2011; 108(Suppl 1):4680-4687. [PubMed: 20534435] 
19. Hawes SE, Hillier SL, Benedetti J, Stevens CE, Koutsky LA, Wolner-Hanssen P, Holmes KK. Hydrogen peroxide-producing lactobacilli and acquisition of vaginal infections. J Infect Dis. 1996; 174:1058-1063. [PubMed: 8896509]

20. Martin HL, Richardson BA, Nyange PM, Lavreys L, Hillier SL, Chohan B, Mandaliya K, NdinyaAchola JO, Bwayo J, Kreiss J. Vaginal lactobacilli, microbial flora, and risk of human immunodeficiency virus type 1 and sexually transmitted disease acquisition. J Infect Dis. 1999; 180:1863-1868. [PubMed: 10558942]

21. Schwebke JR. Role of vaginal flora as a barrier to HIV acquisition. Curr Infect Dis Rep. 2001; 3:152-155. [PubMed: 11286657]

22. Taha TE, Hoover DR, Dallabetta GA, Kumwenda NI, Mtimavalye LA, Yang LP, Liomba GN, Broadhead RL, Chiphangwi JD, Miotti PG. Bacterial vaginosis and disturbances of vaginal flora: association with increased acquisition of HIV. AIDS. 1998; 12:1699-1706. [PubMed: 9764791]

23. van De Wijgert JH, Mason PR, Gwanzura L, Mbizvo MT, Chirenje ZM, Iliff V, Shiboski S, Padian NS. Intravaginal practices, vaginal flora disturbances, and acquisition of sexually transmitted diseases in Zimbabwean women. J Infect Dis. 2000; 181:587-594. [PubMed: 10669342]

24. Zheng HY, Alcorn TM, Cohen MS. Effects of H2O2-producing lactobacilli on Neisseria gonorrhoeae growth and catalase activity. J Infect Dis. 1994; 170:1209-1215. [PubMed: 7963715]

25. Boris S, Barbés C. Role played by lactobacilli in controlling the population of vaginal pathogens. Microbes Infect. 2000; 2:543-546. [PubMed: 10865199]

26. Herthelius M, Gorbach SL, Möllby R, Nord CE, Pettersson L, Winberg J. Elimination of vaginal colonization with Escherichia coli by administration of indigenous flora. Infect Immun. 1989; 57:2447-2451. [PubMed: 2663724]

27. McGroarty JA, Reid G. Detection of a Lactobacillus substance that inhibits Escherichia coli. Can J Microbiol. 1988; 34:974-978. [PubMed: 3145135]

28. McGroarty JA, Tomeczek L, Pond DG, Reid G, Bruce AW. Hydrogen peroxide production by Lactobacillus species: correlation with susceptibility to the spermicidal compound nonoxynol-9. J Infect Dis. 1992; 165:1142-1144. [PubMed: 1316413]

29. Osset J, Bartolomé RM, García E, Andreu A. Assessment of the capacity of Lactobacillus to inhibit the growth of uropathogens and block their adhesion to vaginal epithelial cells. J Infect Dis. 2001; 183:485-491. [PubMed: 11133381]

30. Reid G, Cook RL, Bruce AW. Examination of strains of lactobacilli for properties that may influence bacterial interference in the urinary tract. J Urol. 1987; 138:330-335. [PubMed: 3599250]

31. Reid G, Heinemann C, Velraeds M, van der Mei HC, Busscher HJ. Biosurfactants produced by Lactobacillus. Methods Enzymol. 1999; 310:426-433. [PubMed: 10547809]

32. Stamey TA, Kaufman MF. Studies of introital colonization in women with recurrent urinary infections. II. A comparison of growth in normal vaginal fluid of common versus uncommon serogroups of Escherichia coli. J Urol. 1975; 114:264-267. [PubMed: 240039]

33. Andreu A, Stapleton AE, Fennell CL, Hillier SL, Stamm WE. Hemagglutination, adherence, and surface properties of vaginal Lactobacillus species. J Infect Dis. 1995; 171:1237-1243. [PubMed: 7751699]

34. Butler D, Silvestroni A, Stapleton A. Cytoprotective effect of Lactobacillus crispatus CTV-05 against uropathogenic E. coli. Pathogens. 2016; 5:27.

35. O'Hanlon DE, Moench TR, Cone RA. Vaginal $\mathrm{pH}$ and microbicidal lactic acid when lactobacilli dominate the microbiota. PLoS One. 2013; 8:e80074.doi: 10.1371/journal.pone.0080074 [PubMed: 24223212]

36. Hooton, TM., Stamm, WE. The vaginal flora and urinary tract infections. In: Warren, JW., Mobley, HL., editors. Urinary Tract Infections: Molecular Pathogenesis and Clinical Management. ASM Press; Washington, DC: 1996.

37. Schaeffer AJ, Jones JM, Amundsen SK. Bacterial effect of hydrogen peroxide on urinary tract pathogens. Appl Environ Microbiol. 1980; 40:337-340. [PubMed: 6781405]

38. Klebanoff SJ, Hillier SL, Eschenbach DA, Waltersdorph AM. Control of the microbial flora of the vagina by $\mathrm{H}_{2} \mathrm{O}_{2}$-generating lactobacilli. J Infect Dis. 1991; 164:94-100. [PubMed: 1647428] 
39. Pfau A, Sacks T. The bacterial flora of the vaginal vestibule, urethra and vagina in premenopausal women with recurrent urinary tract infections. J Urol. 1981; 126:630-634. [PubMed: 7029007]

40. Stamey TA, Sexton CC. The role of vaginal colonization with enterobacteriaceae in recurrent urinary infections. J Urol. 1975; 113:214-217. [PubMed: 803573]

41. Gupta K, Stapleton AE, Hooton TM, Roberts PL, Fennell CL, Stamm WE. Inverse association of $\mathrm{H} 2 \mathrm{O} 2$-producing lactobacilli and vaginal Escherichia coli colonization in women with recurrent urinary tract infections. J Infect Dis. 1998; 178:446-450. [PubMed: 9697725]

42. Hooton TM, Fihn SD, Johnson C, Roberts PL, Stamm WE. Association between bacterial vaginosis and acute cystitis in women using diaphragms. Arch Intern Med. 1989; 149:1932-1936. [PubMed: 2673116]

43. Hooton TM, Roberts PL, Stamm WE. Effects of recent sexual activity and use of a diaphragm on the vaginal microflora. Clin Infect Dis. 1994; 19:274-278. [PubMed: 7986899]

44. Kirjavainen PV, Pautler S, Baroja ML, Anukam K, Crowley K, Carter K, Reid G. Abnormal immunological profile and vaginal microbiota in women prone to urinary tract infections. Clin Vaccine Immunol. 2009; 16:29-36. [PubMed: 19020112]

45. Hooton TM, Scholes D, Gupta K, Stapleton AE, Roberts PL, Stamm WE. Amoxicillin-clavulanate vs ciprofloxacin for the treatment of uncomplicated cystitis in women: a randomized trial. JAMA. 2005; 293:949-955. [PubMed: 15728165]

46. Raz R. Urinary tract infection in postmenopausal women. Korean J Urol. 2011; 52:801-808. [PubMed: 22216390]

47. Raz R. Hormone replacement therapy or prophylaxis in postmenopausal women with recurrent urinary tract infection. J Infect Dis. 2001; 183(Suppl 1):S74-S76. [PubMed: 11171020]

48. Raz R, Stamm WE. A controlled trial of intravaginal estriol in postmenopausal women with recurrent urinary tract infections. N Engl J Med. 1993; 329:753-756. [PubMed: 8350884]

49. Cauci S, Driussi S, De Santo D, Penacchioni P, Iannicelli T, Lanzafame P, De Seta F, Quadrifoglio F, de Aloysio D, Guaschino S. Prevalence of bacterial vaginosis and vaginal flora changes in periand postmenopausal women. J Clin Microbiol. 2002; 40:2147-2152. [PubMed: 12037079]

50. Muhleisen AL, Herbst-Kralovetz MM. Menopause and the vaginal microbiome. Maturitas. 2016; 91:42-50. [PubMed: 27451320]

51. Pabich WL, Fihn SD, Stamm WE, Scholes D, Boyko EJ, Gupta K. Prevalence and determinants of vaginal flora alterations in postmenopausal women. J Infect Dis. 2003; 188:1054-1058. [PubMed: 14513427]

52. Eriksen B. A randomized, open, parallel-group study on the preventive effect of an estradiolreleasing vaginal ring (Estring) on recurrent urinary tract infections in postmenopausal women. Am J Obstet Gynecol. 1999; 180:1072-1079. [PubMed: 10329858]

53. Shen J, Song N, Williams CJ, Brown CJ, Yan Z, Xu C, Forney LJ. Effects of low dose estrogen therapy on the vaginal microbiomes of women with atrophic vaginitis. Sci Rep. 2016; 6:24380.doi: 10.1038/srep24380 [PubMed: 27103314]

54. Mody L, Juthani-Mehta M. Urinary tract infections in older women: a clinical review. JAMA. 2014; 311:844-854. [PubMed: 24570248]

55. Stokholm J, Schjørring S, Eskildsen CE, Pedersen L, Bischoff AL, Følsgaard N, Carson CG, Chawes BL, Bønnelykke K, Mølgaard A, Jacobsson B, Krogfelt KA, Bisgaard H. Antibiotic use during pregnancy alters the commensal vaginal microbiota. Clin Microbiol Infect. 2014; 20:629635. [PubMed: 24118384]

56. Mayer BT, Srinivasan S, Fiedler TL, Marrazzo JM, Fredricks DN, Schiffer JT. Rapid and profound shifts in the vaginal microbiota following antibiotic treatment for bacterial vaginosis. J Infect Dis. 2015; 212:793-802. [PubMed: 25676470]

57. Macklaim JM, Clemente JC, Knight R, Gloor GB, Reid G. Changes in vaginal microbiota following antimicrobial and probiotic therapy. Microb Ecol Health Dis. 2015; 26:27799. [PubMed: 26282697]

58. Smith HS, Hughes JP, Hooton TM, Roberts P, Scholes D, Stergachis A, Stapleton A, Stamm WE. Antecedent antimicrobial use increases the risk of uncomplicated cystitis in young women. Clin Infect Dis. 1997; 25:63-68. [PubMed: 9243034] 
59. Hooton TM, Roberts PL, Stapleton AE. Cefpodoxime vs ciprofloxacin for short-course treatment of acute uncomplicated cystitis: a randomized trial. JAMA. 2012; 307:583-589. [PubMed: 22318279]

60. Gupta K, Hooton TM, Naber KG, Wullt B, Colgan R, Miller LG, Moran GJ, Nicolle LE, Raz R, Schaeffer AJ, Soper DE. Infectious Diseases Society of America, European Society for Microbiology and Infectious Diseases. International clinical practice guidelines for the treatment of acute uncomplicated cystitis and pyelonephritis in women: a 2010 update by the Infectious Diseases Society of America and the European Society for Microbiology and Infectious Diseases. Clin Infect Dis. 2011; 52:e103-e120. [PubMed: 21292654]

61. Eschenbach DA, Patton DL, Meier A, Thwin SS, Aura J, Stapleton A, Hooton TM. Effects of oral contraceptive pill use on vaginal flora and vaginal epithelium. Contraception. 2000; 62:107-112. [PubMed: 11124356]

62. Gupta K, Hillier SL, Hooton TM, Roberts PL, Stamm WE. Effects of contraceptive method on the vaginal microbial flora: a prospective evaluation. J Infect Dis. 2000; 181:595-601. [PubMed: 10669343]

63. Hooton TM, Hillier S, Johnson C, Roberts PL, Stamm WE. Escherichia coli bacteriuria and contraceptive method. JAMA. 1991; 265:64-69. [PubMed: 1859519]

64. Hooton TM, Scholes D, Roberts PL, Stapleton A, Stergachis A, Stamm WE. A prospective cohort study of the association between UTI and contraceptive method. Abstr Intersci Conf Antimicrob Agents Chemother. 1994; 34:134.

65. Hooton TM, Fennell CL, Clark AM, Stamm WE. Nonoxynol-9: differential antibacterial activity and enhancement of bacterial adherence to vaginal epithelial cells. J Infect Dis. 1991; 164:12161219. [PubMed: 1659602]

66. Achilles SL, Hillier SL. The complexity of contraceptives: understanding their impact on genital immune cells and vaginal microbiota. AIDS. 2013; 27(Suppl 1):S5-S15. [PubMed: 24088684]

67. Stamm WE, McKevitt M, Roberts PL, White NJ. Natural history of recurrent urinary tract infections in women. Rev Infect Dis. 1991; 13:77-84. [PubMed: 2017637]

68. Stapleton AE, Au-Yeung M, Hooton TM, Fredricks DN, Roberts PL, Czaja CA, Yarova-Yarovaya Y, Fiedler T, Cox M, Stamm WE. Randomized, placebo-controlled phase 2 trial of a Lactobacillus crispatus probiotic given intravaginally for prevention of recurrent urinary tract infection. Clin Infect Dis. 2011; 52:1212-1217. [PubMed: 21498386]

69. Schwenger EM, Tejani AM, Loewen PS. Probiotics for preventing urinary tract infections in adults and children. Cochrane Database Syst Rev. 2015; 12:CD008772. 